\title{
イミダゾール系化合物の合成と生物活性に関する研究
}

\author{
桑 野栄一
}

九州大学農学部農芸化学科

\section{Studies on the Synthesis and Biological Activity of Imidazole Compounds}

\author{
Eiichi KUwANO \\ Department of Agricultural Chemistry, Kyushu University, Hakozaki, Fukuoka 812, Japan
}

はじめに

新しい生理活性物質の開発にはまず，その手がかりとな るリード化合物をいかにして見出すかがもっとも重要なポ イントになる．まったく新しいリード化合物の発見という ものはこれまで，天然物の探索によるか，あるいは合成化 合物の無差別スクリーニングによりなされた場合がほとん どであり，リード化合物を発見するいわゆるリードジェネ レーションの合理的な方法について，さまざまな観点から のアプローチ・模索が現在試みられている。これまでに蓄 積されてきた生化学的知見を基に分子設計を試みる生合理 的アプローチは有効な方法の一つであり, 酵素や受容体の 構造および機能が解明されるにつれて，それらに基づいた 薬物の分子設計が行なわれている。一方では，新しい生理 活性物質がさきに発見されたことにより，それが作用する 酵素あるいは受容体の構造や機能が解明された例も多く， 新しい生理活性物質は薬としてだけでなく，分子プローブ として生命現象の解明には不可欠なものとなっている.

本研究は生合理的アプローチの一つとして，すでにチト クローム P450 阻害活性が知られているイミダゾール化合 物を利用し，主として昆虫成育制御物質の分子設計を行 なったものである．その結果得られた新規イミダゾール化 合物の生物活性, すなわち, 幼若ホルモン生合成阻害, 抗 脱皮ホルモン活性，殺虫活性，休眠制御活性，植物白化作 用等について概説する。

\section{幼若ホルモン (JH) 生合成阻害剤の分子設計}

昆虫の脱皮と変態は，脳，アラ夕体，前胸腺からそれぞ れ分泌される前胸腺刺激ホルモン, 幼若ホルモン $(\mathrm{JH})$, 脱
皮ホルモンなどにより誘導, 制御されている。とくに, JH は脱皮, 変態のほか, 休眠, 生殖腺刺激作用, フェロモン の生合成等種々の生理作用に関与していることから, 抗 JH 活性物質は昆虫生命現象の解明に役立つばかりでなく, 新 しい昆虫成育制御郕として有望である ${ }^{1)}$ 。そこでまず，JH 生合成阻害剂の分子設計を試みた。

JH はアラ夕体でメバロン酸, あるいはホモメバロン酸を 経由するテルペノイド生合成経路によって合成される。こ の経路の前半はステロイド類等種々の生体物質の生合成経 路と共通しており，この部分の阻害剤は選択性に乏しいと 考えられる. JH 生合成経路の後半部分たとえば JH III の 場合, farnesoic acid のメチルエステル化とエポキシ化であ ク，この経路は哺乳動物にはないことから，この段階の阻 害剂は特異性の高いものが期待できる（Fig. 1)。また，ア ラ夕体培養系に farnesoic acid を添加すると JH III の合成 が著しく増加することから， $O$-methyl transferase と methyl farnesoate 10,11-epoxidase (MFE) の活性が高いことが明 らかにされている2. ゴキブリやバッタのアラタ体ミクロ ゾーム画分に存在する MFE は NADPH および酸素を必 要とし, 一酸化炭素, ピペロニルブトキシドさらにある種 のイミダゾール化合物によって阻害されることから，チト クロームP450であることが示唆されている31.

P450は一般に一原子酸素添加酵素であり, その生理的役 割と基質特異性から，二つに大別できる。一つはさまざま な外来性低分子化合物の酸化的代謝を担っている P450 で,このような P450 分子種は多数存在しており, 基質特異 性は非常に幅広い。もう一つはステロイドホルモン, ビ夕 ミン, 胆汁酸, トロンボキサン等重要な生体内物質の生合 成および不活性化などに関与している P450 分子種で，そ 


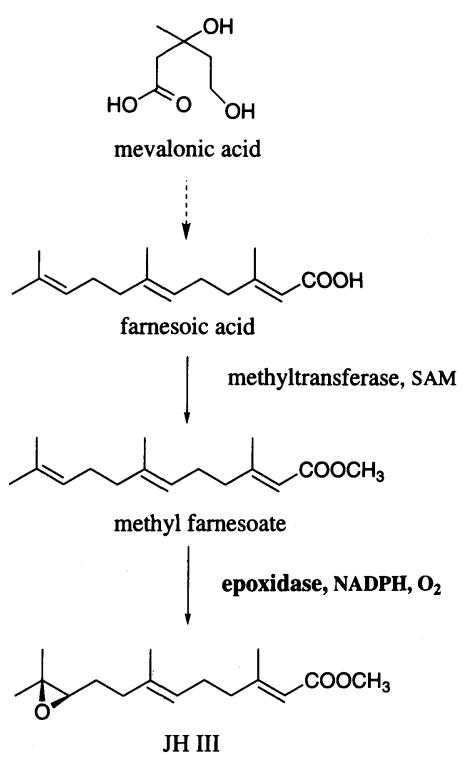

Fig. 1 JH III biosynthetic pathway.

れらの基質特異性は高いことが明らかにされている。 JH 生 合成経路の MFE は当然, 基質特異性が高いことが予想さ れる.

一方, 薬物代謝に関与寸る $\mathrm{P} 450$ の阻害剂として, 1-置換 あるいは 4-置換イミダゾール類が Wilkinson らによって 精力的に調べられており，殺虫剂に対して共力作用を示す ことが報告されている4)。また，その阻害作用は $\mathrm{P} 450$ の活 性中心であるへム鉄にイミダゾール環 3 位の $\mathrm{sp}^{2}$ 窒素が配 位することで起こることが明らかにされている5

以上の知見を基に MFEの阻害剂の分子設計を行なっ た。すなわち，P450 阻害活性発現部位としてイミダゾール を使用し，これに酵素の活性中心付近にある疎水性部位と の親和性を高めるため, 基質である methyl farnesoate と類 似した構造を導入することを考えた。すすでに数多くの JH 類縁体が発見されており，それらの構造を参考にして，ゲ ラニール基，フェノキシフェニル基，ベンジルオキシフェ ニル基あるいはそれらの類似骨格をイミダゾール環に導入 した化合物を合成した ${ }^{6 \sim 9)}$.

\section{幼若ホルモン生合成阻害活性}

ゴキブリのアラタ体培養系に $\left[\right.$ methyl $\left.-{ }^{14} \mathrm{C}\right]$ methionine を 添加し，生成する ${ }^{14} \mathrm{C}$ でラベルされた JH III を定量する in vitro JH III 生合成系を使用し, 種々のイミダゾール化合物 の阻害活性を検討した ${ }^{10,11)}$. 代表的な化合物の JH III 生合 成阻害活性と培地中に蓄積してくる methyl farnesoate (MF)の量を Table 1 に示した. 化合物が MF から JH III へ のエポキシ化を阻害すれば，MF が培地中に多量に蓄積し てくるはずである。一般に，1-置換 5-(3-ベンジルオキシ フェニル)イミダゾールが顕著な阻害活性を示し，1 位の置
Table 1 Inhibition of $\mathrm{JH}$ synthesis and accumulation of methyl farnesoate (MF) by 1,5-disubstituted imidazoles in corpora allata of the cockroach, Diploptera punctata.

(pir)

nd : none detected.

換基として，ベンジル，メチル，エチル，イソプロピル (TH-20)，イソブチル (TH-27) 基等の場合に強い活性がみ られ， $n$-ブチル，ネオペンチル基では低下した．とくに， TH-27 に強い JH III 生合成阻害活性と MF の多量蓄積が 認められ，この場合，MF の前駆体である farnesoic acid を 添加しても阻害活性にまったく影響はなかった。さらに, アラタ体ホモジネート中の MFEに対する阻害活性を methyl $(2 Z, 6 E)$ farnesoate を基質として調べた結果，TH-27 の $\mathrm{IC}_{50}$ 值は $7.4 \mathrm{nM}$ と強い阻害を示した。一方, 1-citronellyl5-(2-ethoxyphenyl)imidazole（KK-51）の JH 生合成阻害活 性はTH-27 より弱いが，MF をまったく蓄積させないこと から, MF 以前の生合成経路を抑制していると考之られ, こ れをリードとして，新たな JH 生合成阻害片の開発が期待 できる.

Feyereisen らはMFEに対して強い阻害活性を示した TH-27 のトリチウムラベルおよびベンゾフェノン基を導 入した化合物 (TH-27-BP) を使用し，光アフィニティラベ ル法により，アラタ体ホモジネート中から MFE と思われ

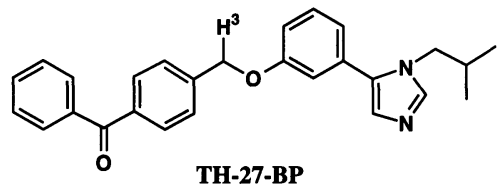




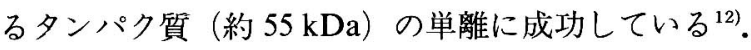

\section{早熟変態誘起活性と抗脱皮ホルモン活性}

カイコ 4 齢幼虫からアラ夕体を摘出すると, 幼虫は 5 齢 に脱皮せず早熟的に蛹化する. 抗 JH 活性物質の明確な生 物検定法として, 化合物を終龄の一つ前の幼虫に処理して, アラタ体を摘出した場合と同様な早熟変態が誘導されるか ぞうかを調べる方法が知られている11. そこで，JH 生合成 阻害剤として分子設計した種々のイミダゾール化合物を, カイコ 4 齢幼虫に局所施用して早熟変態誘起活性を検討し た.その結果, Table 2 に示すようにさまざまな 1, 5-二置換 イミダゾール類に活性が認められた ${ }^{13 \sim 19)}$. 1 位の置換基と して，ベンジル，イソブチル，ネオペンチル基等がとくに 強い活性を示し, また, ゲラニルやシトロネリル基等 JH 様 テルペン鎖のほか, $n$-オクチル基にも強い活性が認められ た.この生物検定法では KK-42 がもっとも強い活性を示 し，3 齢に対しても早熟変態を誘導した（Fig. 2). 前述の TH-27のカイコに対する早熟変態誘起活性は KK-42 の 1/ 100 以下であり，カイコに対寸る早熟変態誘起活性とゴキ ブリのアラ夕体を用いた in vitro JH III 生合成阻害活性と はまったく相関が認められなかった。これについては昆虫 種によって利用するJHの種類が異なる（カイコ幼虫では

Table 2 Induction of precocious metamorphosis in the 4th instar larvae of the silkworm by 1,5-disubstituted imidazoles.

(1)

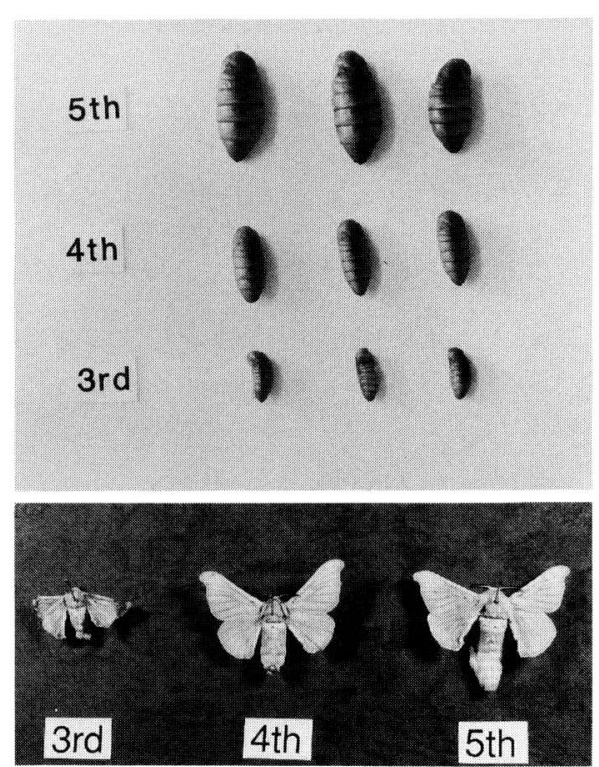

Fig. 2 Effect of KK-42 on 3rd- and 4th-instar larvae of Bombyx mori.

(5th) Normal pupae and adult, (4th) precocious pupae and adult induced by treating 4th-instar larvae, (3rd) precocious pupae and adult induced by treating 3rd-instar larvae.

JH I と JH II で，ゴキブリでは JH III）など昆虫間の生理的 相違が考えられたが, 以下に述べるように KK-42の作用と JH とはほとんど関係なかった。

アラ夕体摘出で生じる早熟変態（抗 JH 活性）と KK-42 の早熟変態誘起活性を 4 齢カイコを用いて詳細に比較検討 した結果，前者では 4 齢のごく初期に処理した場合のみ効 果があるのに対し，後者では 4 齢中期に処理してもその効 果が認められた。また，KK-42 処理後数日間以上, 幼虫体 液中には脱皮ホルモンが検出されず，4 齢期間が大幅に延 長することがわかった ${ }^{20)}$. 脱皮ホルモンの分泌遅れにより， キチナーゼとグルコサミナーゼの発現時期も晴れた ${ }^{21)}$ 。さ らに，蛹化直後に KK-42 を处理すると，蛹体液中の脱皮木 ルモン量が減少し羽化が著しく遅延したが，この症状は 20-hydroxyecdysone を注射すると完全に回復した ${ }^{22)}$. 以上 のことから，KK-42 が脱皮ホルモンの分泌を特異的に阻害 していることが明らかとなった。

脱皮ホルモン合成能が高い 5 齢幼虫 7 日目の培養前胸腺 を用いた実験で，KK-42は $100 \mathrm{nM} て ゙$ 脱皮ホルモンの合成 を $90 \%$ 以上阻害し， $I_{50}$ 值は約 $1 \mathrm{nM}$ ときわめて強い活性を 示した ${ }^{23)}$. また，KK-42 はバッ夕の培盖前胸腺においても 脱皮ホルモンの生合成を阻害し, 前胸腺を KK-42を含まな い培地に移すと，ホルモン合成能が回復した ${ }^{24,25)}$.これらの ことから, KK-42 は前胸腺での脱皮ホルモンの生合成を阻 害することが明確となった。

そこで, 早熟変態誘起活性を示す種々の 1,5-二置換イミ ダゾール化合物について，脱皮ホルモンとの関連を検討し 
た. その結果, Table 2 に示した化合物の早熟変態誘起活性 は20-hydroxyecdysone を捸食させるか，あるいは脱皮ホル モンアゴニストであるテブフェノチドを微量局所施用する ことにより完全に打ち消されることがわかった ${ }^{26,27)}$.これ は上記 1,5-二置換イミダゾールが幼虫体液中の脱皮ホル モン量を抑制（恐らく，KK-42 と同様に脱皮ホルモン生合 成を阻害）することによって早熟変態を誘導していること を示している。

早熟変態はアラ夕体摘出など JH の欠乏によって起こる ことはすでに知られているが，脱皮ホルモン作用が一時的 に抑制されることによっても誘導されることが明らかと なった. 最近, 1, 5-二置換イミダゾールだけでなく, 1-置換 イミダゾールにも早熟変態誘起活性があることを見出し た $^{28)}$.これまでに脱皮ホルモンの有効な阻害剂はなく,これ らの化合物は内分泌制御機構解明に貢献できると思われ る.

昆虫はステロイド骨格を生合成できないため，脱皮ホル モンを食餌中の $\beta$-sitosterol や stigmasterol などの植物性ス テロイド類から合成している (Fig. 3). Cholesterol から 20-hydroxyecdysone への生合成過程では数種の P450 が関 与していることが知られており, Table 2 の化合物はこの酸 化過程を阻害している可能性が高い. Reesらは卵巣におけ る脱皮ホルモン生合成経路において，KK-42 がエクダイソ ン 22 位の水酸化を阻害することを指摘している ${ }^{29}$.

20-Hydroxyecdysone は ecdysoneより脱皮ホルモン活性 が強いことから, 従来, 脱皮ホルモンの本体であろうと考 えられていたが, 最近, 両者間で異なった生理作用が見出 されており，それぞれの生理的役割が違うことが推察され ている ${ }^{30)}$. Ecdysone から 20-hydroxyecdysone への酸化は脂 肪体に存在する ecdysone 20-monooxygenase (P450)によっ て触媒される．Darvas らはニクバエ幼虫脂肪体のミクロ ゾーム画分に存在する 20-monooxygenase を 1,5-二置換イ ミダゾールが阻害することを認めている (Table 3) ${ }^{31)}$. この

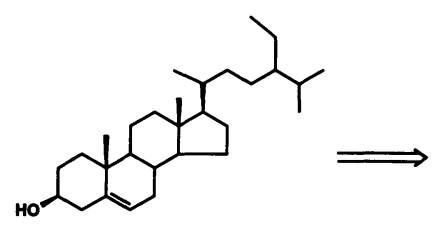

$\beta$-sitosterol

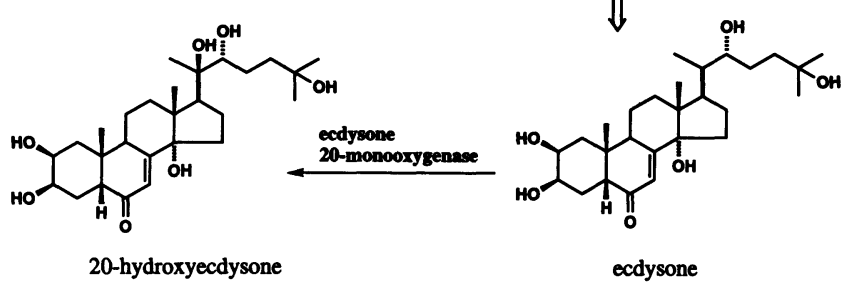

Fig. 3 Ecdysteroid biosynthetic pathway.
なかで KK-110はニクバエに対して早熟変態を誘起し $た^{32} \cdot 1,5$-二置換イミダゾール化合物を利用して, 脱皮ホル モンの生合成経路に関与する $\mathrm{P} 450$ 分子種それぞれについ て特異的阻害剂の分子設計が可能と思われる。

\section{殺 虫 活 性}

前述のように, 種々の 1,5-二置換イミダゾールがカイコ に対して脱皮ホルモンの分泌を抑之早熟変態を誘導した。 この場合，化合物を 4 齢初期に多量局所施用しても 4 齢期 間が少々延長するだけで, 早熟蛹化が誘導された. しかし, 5 齿幼虫後半に処理した場合, 蛹化が起きず幼虫のまま死 亡したり，幼虫一蛹の中間体が生じた ${ }^{33}$. 脱皮ホルモンを抑 制すれば当然脱皮あるいは変態が擋乱されることから，新 しい成育制御物質として期待できる。そこで，カメムシの 一種 Oncopeltus fasciatus の幼虫に対して生物検定を行 なった ${ }^{34)}$.これは抗 $\mathrm{JH}$ 活性物質であるプレコセン類の発 見で使用された昆虫であり，イミダゾール化合物は当初， $\mathrm{JH}$ 生合成阻害剂として分子設計されたことから，抗 JH 活 性も同時に検討する目的があった。この検定法はシャーレ に化合物を塗布し，若㱓幼虫を放つ方法で，幼虫は成育期 間中化合物に曝されることになる。

その結果, O. fasciatus 幼虫に対して,プレコセン様の早 熟変態誘起活性を示すイミダゾール化合物を見出すことが

Table 3 Inhibition of microsomal ecdysone 20-monooxygenase of fat body of Neobellieria bullata wandering stage larvae by imidazoles.

\begin{tabular}{lc}
\hline Compound & $\mathrm{I}_{50}(\mu \mathrm{M})$ \\
\hline KK-110 & 0.2 \\
KK-135 & 1.2 \\
KK-42 & 1.9 \\
\hline
\end{tabular}

Table 4 Insecticidal activity of 1,5-disubstituted imidazoles against the milkweed bug, Oncopeltus fasciatus, and the brown rice planthopper, Nilaparvata lugens.

\begin{tabular}{|c|c|c|c|c|}
\hline \multirow{3}{*}{ Compound } & \multicolumn{4}{|c|}{ Mortality (\%) } \\
\hline & \multicolumn{2}{|c|}{$\begin{array}{l}\text { O. } \text { fasciatus }^{\mathrm{a})} \\
(\mu \mathrm{g} / \mathrm{dish})\end{array}$} & \multicolumn{2}{|c|}{$\begin{array}{l}\text { N. lugens }{ }^{\mathrm{b})} \\
(\mathrm{ppm})\end{array}$} \\
\hline & 50 & 10 & 50 & 5 \\
\hline KK-42 & 0 & 0 & - & - \\
\hline TH-68 & 35 & 0 & B & - \\
\hline KK-80 & 40 & 35 & A & D \\
\hline ТН-67 & 100 & 100 & A & - \\
\hline TH-58 & 100 & 100 & A & B \\
\hline TH-27 & 100 & 25 & A & - \\
\hline TH-32 & 100 & 100 & B & B \\
\hline TH-20 & 100 & 45 & A & D \\
\hline
\end{tabular}

a) 3rd instar larvae.

b) 3rd instar larvae. Mortality : A, 100\% ; B, 99-90\% ; C, 8980\% ; D, 79-50\% ; - , 49-0\%. 
できなかった．しかし，Table 4 に示すように，殺虫活性が 認められた。とくに, 化合物 TH-32 および TH-58 等 1-イソ ブチルイミダゾール類が強い活性を示した。これらの化合 物を 3 龄幼虫に処理した場合, 速効的致死効果, 発育の遅 れ等はまったくみられず，脱皮時のみに異常が認められ， 脱皮不能あるいは脱皮直後の致死作用であった. また, 5 龄 幼虫に処理した場合, 古い表皮が脱げず成虫への変態が阻 止された。これらの症状は脱皮ホルモン阻害によるものと 考えられる. しかし，KK-42 はO. fasciatus 幼虫に対して 高薬量でも活性を示さず, 1, 5-二置換イミダゾールのカイ コに対する早熟変態誘起活性とO. fasciatus 幼虫に対する 殺虫活性との間では，相関関係はまったく認められなかっ た。

O. fasciatus に殺虫活性を示したことから，同じ半翅目で あるトビイロウンカ幼虫に対して検討したところ，ある程 度の殺虫活性が認められた (Table 4)。この場合, O. fasciatus の場合と同样, 脱皮阻害による殺虫効果であり, 構造 と活性の関係も同じ傾向がみられた。これらの殺虫活性物 質については現在も検討中である。

\section{休眠制御作用}

昆虫は, 卵, 幼虫, 蛹, そして成虫とさまざまな発育ス テージで休眠する，カイコと同様その菊系が織物に利用さ れている天蚕 (Antheraea yamamai) は卵期で休眠越冬す る.この休眠はカイコ卵の場合と異なり，すでに卵殼中に 幼虫の体が形成されている前幼虫態休眠である. 従来, こ の休眠覚醒には 60 日以上の冷蔵が必要であり, これ以外の 方法では休眠を破ることができなかった．岩手大学の鈴木 らはこの前幼虫態休眠を KK-42によって覚醒できること を発見し，KK-42 を用いた天蚻の人工酻化法を確立してい $3^{35 \sim 37)}$.

構造と休眠覚醒活性の関係を Table 5 に示した ${ }^{38)}$. 卵に 化合物 $20 \mu \mathrm{g}$ を塗布して $25^{\circ} \mathrm{C}$ に保存した場合の活性を示 しており，無処理ではまったく休眠覚醒は起きなかった。 一般に, カイコに対して早熟変態誘起活性が強い化合物が 高い休眠覚醒率を示し, 処理後 20 日以内で脬化を誘導し た.また，卵款を取り除いて KK-42を処理すると $0.05 \mu \mathrm{g}$ で休眠を破ることができた。

この休眠覚醒前後において, 脱皮ホルモン量の変動がな いこと, また, メソプレンや JH I を処理しても休眠に影響 を与えないことなどから, 休眠制御には脱皮ホルモンと JH が関与していないことが確認されている．鈴木らはこの前 幼虫態休眠制御機構には二種類の新しいペプチドホルモ ン, 寸なわち, 発育を抑之て休眠状態を保つ抑制因子と休 眠を破る成熟因子が存在することを明らかにしてい $ろ^{39 \sim 41)}$.

また，天蚕と同様に前幼虫態休眠を行なう森林害虫マイ
Table 5 Effects of imidazoles on the termination of diapause in eggs of the silkmoth, Antheraea yamamai.

\begin{tabular}{ccc} 
Hatchability & $\begin{array}{c}\text { Average days } \\
\text { (\%) }\end{array}$ & $\begin{array}{c}14.0 \pm 4.3 \\
\text { required for } \\
\text { (daytching }\end{array}$ \\
\hline Sampound $)$
\end{tabular}

マイガに対しても，KK-42 は覚醒作用を示したことから， 上記イミダゾール化合物は前幼虫態で休眠する昆虫に対し て普遍的に覚醒作用を示寸ものと思われる ${ }^{42)}$.

P450 阻害性イミダゾール化合物が休眠覚醒作用を有す ることは非常に興味深い。休眠中は酸素消費量が極端に低 下している状態である．分子状酸素を利用して基質に 1 原 子の酸素を添加する $\mathrm{P} 450$ が休眠制御に関与している可能 性も考えられる．イミダゾール化合物の休眠覚醒作用に端 を発して, 前幼虫態休眠機構の解明が進められている.

一方，力イコは胚発育の初期に休眠に入る。 カイコ野生 品種「大造」は卵の時期の環境により休眠性が決定される。 暗黒下低温で脬化させた場合, 成長した雌の蛾は交尾後非 休眠卵を産む。 逆に, 光照射下高温で扸孚化させた場合, 蛹 時期に休眠ホルモンが分泌され，成虫は休眠卵を産む．以 上のように，このカイコでは卵の時期の環境情報が蛹まで 維持され，ホルモン制御系へ伝達されていることが知られ ている．最近，この休眠卵を産むよう運命づけられている 大造力イコの 5 齢幼虫に KK-42 を処理すると, 非休眠卵を 産む蛾が出現することを発見した. 5 齢脱皮後 48 時間に処 理した場合にもっとも効果的であった ${ }^{43}$. 現在, さらに有効 な化合物を検索中であり，休眠性を完全に変換できるよう な活性物質を開発できれば，環境因子の情報受容, 維持そ してホルモン制御系の作動といった休眠に関する情報伝達 機構の解明に貢献できると思われる。

\section{殺虫共力作用}

種々の 1-置換および4-置換イミダゾールが薬物代謝に 関与する P450を阻害し, カーバメイト系殺虫剤に対して 
共力作用を示すことが報告されている4). そこで, 数種の 1, 5-二置換イミダゾール化合物について感受性イエバエを 用いて，ピレスロイド系殺虫剤ペルメトリンに対する共力 効果を検討したところ, KK-42, TH-27, LN-32 等 1, 5-二置 換イミダゾール類にはほとんど共力作用は認められなかっ た。この共力作用を指標として合成探索した結果，1-(4octyloxyphenyl)imidazole (KW-10) および 1-(4-benzyloxyphenyl)imidazole (AT-1)にピペロニルブトキシドと同等の 活性があることがわかった. 化合物 AT-1 のベンジル基べ ンゼン環上にフッ素や塩素原子を導入すると活性は低下し た (渡辺・桑野: 未発表).

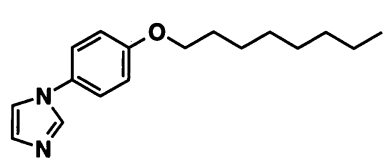

KW-10

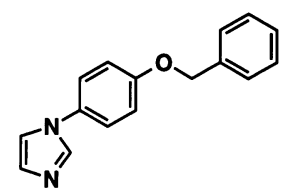

AT-1

\section{植物白化作用}

筆者らが 1, 5-二置換イミダゾール化合物の昆虫成育制 御作用について検討していた頃, 植物生長調節剂として, ジベレリン生合成経路の P450を阻害するアゾール系化合 物が精力的に研究されていた。 そこで，レタスやイネの実 生試験により，1,5-二置換イミダゾール化合物の植物生長 調節作用を調べた ${ }^{44)}$. 数種の化合物に下胚軸の伸長抑制活 性が認められたものの, 当時開発されていた paclobutrazol に比べるときわめて弱いものであった。しかし，1-butyl-5phenylimidazole や 1-butyl-5-(4-methoxyphenyl)imidazole 等が顕著な幼根伸長促進作用を示し， 0.1 ppm でも無処理 区の 1.5 倍以上根を伸長させることがわかった ${ }^{45)}$.

これらの生物検定中，イミダゾール化合物に白化作用が あることを見出した ${ }^{46 \sim 48)}$. 構造と活性の関係を検討した結 果，次のことが明らかとなった（1）1 位と 5 位の置換基 が必須であること。（2）1位の置換基ではエチルとプロピ ル基のみが高い活性を示す，（3） 5 位の置換基として，4クロロフェニル基, 4-(3-メチルベンジル)フェニル基, フェ ネチル基, スチリル基等がよいこと. 代表的化合物 5-[4-(3methylbenzyl)phenyl]-1-propylimidazole (NY-39) と 5-(4chlorophenyl)-1-propylimidazole (NY-70) は葉中のクロロ フィル含量とともにカロチノイド含量を顕著に減少させ, $\beta$-カロチン生合成中間体であるフィトエンを無処理区に 比べ 5 15 倍ほど蓄積させた。このことは他のカロチノイ ド生合成阻害剤と同様, フィトエン脱水素酵素の阻害と考 えられるが，NY-39 と NY-70 処理ではフィトエン蓄積量 が異なり，他の作用機構も考之られる，1,5-二置換イミダ ゾール化合物のみが白化作用を示したことから，ある種の P450 を阻害している可能性も否定できない.

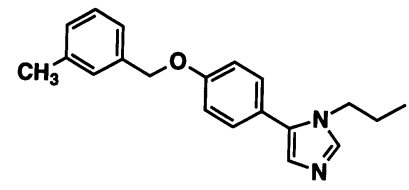

NY-39

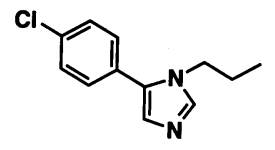

NY-70

\section{おわりに}

チトクロームP450 阻害活性が知られているイミダゾー ル化合物を利用して分子設計を行ない，新規昆虫成育制御 剤開発のためのリード化合物として，また，昆虫の変態お よび休眠制御機構解明のための有力な分子プローブとし て, 幼若ホルモン生合成阻害剂, 脱皮ホルモン生合成阻害 凨, 脱皮阻害剂, 休眠制御物質等を提供することができた. これらの作用機構において，すべて P450が関与している かどうか現在のところわからないが，1,5-二置換イミダ ゾール誘導体であることから，その可能性は高いと考えら れる.P450はきわめて多彩で重要な反応を担っており，そ れらをターゲットとして新しい薬剤が開発されつつある。 今後，それぞれの P450 分子種の基質認識部位の構造が明 らかにされることにより，特異的阻害剂の開発がさらに進 むものと思われる．より合理的な分子設計による新しい生 理活性物質の開発を期待したい.

本研究の遂行にあたり, 終始ご指導, ご鞭撻を賜った九州大学 名誉教授江藤守総先生，同名誉教授谷口栄二先生に心から感謝 の意を表します。研究者の道へ導いていただきました元九州大 学教授前川一之先生に梁く感謝致します。本研究は優れた昆虫 生化学者との共同研究によって行なわれたものであり，とくに， 岩手大学鈴木幸一教授, 名古屋大学山下興亜教授, アリゾナ大学 Feyereisen 教授に心から感謝致しますとともに，栄誉を分かち 合いたいと思います.また，ご協力いただいた関係者に謝意を表 します. 最後に引用文献中に記載させていただいた協力者をは じめ, 九州大学農学部農芸化学科農薬化学講座の皆さまに心か らお礼申し上げます。

\section{引用 文 献}

1) G. B. Staal : Ann. Rev. Entomol. 31, 391 (1986)

2) D. A. Schooley \& F. D. Baker: "Comprehensive Insect Physiology, Biochemistry and Pharmacology," ed. by G. A. Kerkut \& L. I. Gilbert, Pergamon Press, Oxford, pp. 363389,1985

3) B. D. Hammock \& S. M. Mumby : Pestic. Biochem. Physiol. 9, 39 (1978)

4) C. F. Wilkinson, K. Hetnarski \& L. J. Hicks: Pestic. Biochem. Physiol. 4, 299 (1974)

5) P. R. Ortiz de Montellano \& N. O. Reich: "Cytochrome P-450," ed. by P. R. Ortiz de Montellano, Plenum Press, New York, pp. 273-314, 1986

6) E. Kuwano, R. Takeya \& M. Eto : Agric. Biol. Chem. 47, 921 (1983)

7) E. Kuwano, R. Takeya \& M. Eto: Agric. Biol. Chem. 48, 3115 (1984) 
8) E. Kuwano, R. Takeya \& M. Eto : Agric. Biol. Chem. 49, $483(1985)$

9) E. Kuwano, T. Hisano \& M. Eto: Agric. Biol. Chem. 55, 2999 (1991)

10) G. E. Pratt, E. Kuwano, D. E. Farnsworth \& R. Feyereisen : Pestic. Biochem. Physiol. 38, 223 (1990)

11) G. C. Unnithan, J. F. Andersen, T. Hisano, E. Kuwano \& R. Feyereisen : Pestic. Sci. 43, 13 (1995)

12) J. F. Andersen, M. Ceruso, G. C. Unnithan, E. Kuwano, G. D. Prestwich \& R. Feyereisen : Insect Biochem. Mol. Biol. 25, 713 (1995)

13) S. Asano, E. Kuwano \& M. Eto : Appl. Entomol. Zool. 19, $212(1984)$

14) S. Asano, E. Kuwano \& M. Eto: J. Pesticide Sci. 9, 503 (1984)

15) S. Asano, E. Kuwano \& M. Eto : Appl. Entomol. Zool. 21, 63 (1986)

16) S. Asano, E. Kuwano \& M. Eto : Appl. Entomol. Zool. 21, 305 (1986)

17) S. Asano, E. Kuwano \& M. Eto : Appl. Entomol. Zool. 22, 424 (1987)

18) E. Kuwano, M. Kikuchi \& M. Eto : Agric. Biol. Chem. 52, 1619 (1988)

19) E. Kuwano, M. Kikuchi \& M. Eto: J. Fac. Agric. Kyushu Univ. 35, 35 (1990)

20) K. Kadono-Okuda, E. Kuwano, M. Eto \& O. Yamashita : Dev. Growth \& Differ. 29, 527 (1987)

21) D. Koga, T. Funakoshi, H. Fujimoto, E. Kuwano, M. Eto \& A. Ide : Insect Biochem. 21, 277 (1991)

22) K. Kadono-Okuda, E. Kuwano, M. Eto \& O. Yamashita : Appl. Entomol. Zool. 22, 370 (1987)

23) O. Yamashita, K. Kadono-Okuda, E. Kuwano \& M. Eto : Agric. Biol. Chem. 51, 2295 (1987)

24) J.-P. Roussel, M. Kiuchi, H. Akai \& E. Kuwano: C.R. Acad. Sci. Paris, Serie III, 305, 141 (1987)

25) J. P. Roussel, K. Mojtahe-Zadeh, R. Lanet, E. Kuwano \& H. Akai : Arch. Int. Physiol. Biochem. 97, 511 (1989)

26) E. Kuwano, T. Hisano, M. Sonoda \& M. Eto: Biosci. Biotech. Biochem. 58, 1309 (1994)

27) M. Sonoda, E. Kuwano \& E. Taniguchi : J. Pesticide Sci. 20, 325 (1995)

28) K. Shimazu, M. Shimizu, K. Suzuki \& E. Kuwano: J. Pesticide Sci. 21, 337 (1996)

29) T. D. Jarvis, F. G. P. Earley \& H. H. Rees : Pestic. Biochem. Physiol. 48, 153 (1994)
30) Y. Tanaka \& S. Takeda: Naturwissenschaften 80, 131 (1993)

31) B. Darvas, H. H. Rees, N. Hoggard, M. H. Tag El-Din, E. Kuwano, I. Belai \& T. Timar : Pestic. Sci. 36, 135 (1992)

32) B. Darvas, E. Kuwano, M. Eto, M. H. Tag El-Din \& T. Timar : Agric. Biol. Chem. 54, 3045 (1990)

33) E. Kuwano \& M. Eto : Agric. Biol. Chem. 50, 2919 (1986)

34) E. Kuwano, T. Hisano, M. Eto, K. Suzuki, G. C. Unnithan \& W. S. Bowers : Pestic. Sci. 34, 263 (1992)

35）談恩 智・鈴木幸一・桑野栄一・阿部信治・栗原守久：日 䖽雑 55, 305 (1986)

36) K. Suzuki, T. Fujisawa, M. Kurihara, S. Abe \& E. Kuwano: Wild Silkmoth '88, 79 (1989)

37）鈴木幸一・桑野栄一：化学と生物 32, 221 (1994)

38) E. Kuwano, T. Fujisawa, K. Suzuki \& M. Eto : Agric. Biol. Chem. 55, 1185 (1991)

39) K. Suzuki, T. Minagawa, T. Kumagai, S. Naya, Y. Endo, M. Osanai \& E. Kuwano: J. Insect Physiol. 36, 855 (1990)

40) K. Suzuki, S. Naya, T. Kumagai, T. Minagawa, T. Fujisawa \& E. Kuwano: Wild Silkmoth '89.'90, 73 (1991)

41) K. Suzuki, T. Kumagai, S. Naya \& E. Kuwano: Int. J. Wild Silkmoth \& Silk 1, 60 (1994)

42) K. Suzuki, T. Nakakura, T. Yanbe, M. Kurihara \& E. Kuwano: J. Insect Physiol. 39, 107 (1993)

43) C. Wu, K. Suzuki \& E. Kuwano : Biosci. Biotech. Biochem. 60, 1201 (1996)

44) M. Kikuchi, E. Kuwano \& M. Eto : J. Fac. Agric. Kyushu Univ. 34, 397 (1990)

45) M. Kikuchi, E. Kuwano, Y. Nakashima \& M. Eto : J. Fac. Agric. Kyushu Univ. 36, 83 (1991)

46) M. Kikuchi, E. Kuwano, Y. Nakashima \& M. Eto : Biosci. Biotech. Biochem. 56, 161 (1992)

47) N. Yamada, E. Kuwano, M. Kikuchi \& M. Eto: Biosci. Biotech. Biochem. 56, 1943 (1992)

48) N. Yamada, E. Kuwano \& M. Eto: Z. Naturforsch. 48c, 301 (1993)

\section{Studies on the Synthesis and Biological Activity of Imidazole Compounds}

In insects, the growth and development are known to be controlled by at least three major types of hormones, namely the prothoracicotropic hormone (PTTH), the ecdysteroids and the juvenile hormones $(\mathrm{JH})$. PTTH 
secreted from the brain stimulates the prothoracic gland to synthesize and secrete ecdysteroids which initiate the molting. When the amounts of $\mathrm{JH}$ secreted from the corpora allata which is also regulated by the brain is high in the larval stage, a larval-larval molt is induced, whereas secretion of ecdysteroids in the presence of a reduced or absent titer of $\mathrm{JH}$ results in a larval-pupal or larval-adult molt, namely metamorphosis. Disturbing the normal hormone balance causes crucial disorder in the growth and development of insects. Insect growth regulators, whose mode of action are related to molting, metamorphosis, and diapause characteristic to the life cycle of insects, are thought to have fewer harmful effects on non-target species. In this article, the design, various insect growth regulating activities, and structure-activity relationships of a novel series of imidazole compounds are presented.

\section{DESIGN OF INHIBITORS OF JH BIOSYNTHESIS}

Since JH is involved in many physiological functions in insects such as metamorphosis, reproductive and embryogenic events, diapause, and behavior, compounds with anti-JH activity offer a prospective method for selective insect control as well as an effective tool in studies of insect physiology. An attempt was made to find out anti-JH agents that interfere with $\mathrm{JH}$ biosynthesis which is sesquiterpenoid formation via mevalonate or homomevalonate in the corpora allata. The last two enzymatic steps in JH biosynthesis are $O$-methyl transferase and epoxidase, which are the most insect-specific enzymatic processes. Blocking these steps is much preferable with regard to selective toxicity. The epoxidase is a microsomal cytochrome P450 linked enzyme, therefore, the prototype of this class of inhibitor, imidazole derivatives, was designed on the basis of a capacity to bind preferentially a heme iron atom of P450 active site. A number of substituted imidazoles with a JH-like skeleton such as a geranyl, phenoxyphenyl or benzyloxyphenyl group, were synthesized and tested as inhibitors of JH biosynthesis.

Various 1-alkyl-5-(3-benzyloxyphenyl)imidazoles inhibited in vitro JH III biosynthesis in isolated corpora allata from the cockroach, Diploptera punctata, and caused a significant accumulation of methyl farnesoate, suggesting an inhibition of methyl farnesoate epoxidase. These imidazoles were highly potent, with $\mathrm{IC}_{50}$ values of less than $100 \mathrm{nM}$. A radiolabeled and photoactivatable benzophenone group was introduced into 5-(3-benzyloxyphenyl)-1-isobutylimidazole ( $\mathrm{TH}-27)$, one of the best inhibitor, to label the hydrophobic substrate binding site of methyl farnesoate epoxidase. This compound selectively labeled a protein of $c a .55 \mathrm{kDa}$ in corpora allata of the cockroach.

\section{PRECOCIOUS METAMORPHOSIS-INDUCING ACTIVITY AND ANTI-ECDYSTEROID ACTIVITY}

A large number of 1,5-disubstituted imidazoles were evaluated against Bombyx mori larvae for their activity to induce precocious metamorphosis which is recognized as a JH-deficiency symptom. Representative compounds showing marked activity, 1-benzyl-5-[(E)-2, 6dimethyl-1, 5-heptadienyl]imidazole (KK-42), 5-(2-ethoxyphenyl)-1-neopentylimidazole (KK-110), 5-(3-allyloxyphenyl)-1-isobutylimidazole (TH-58) and 5-(2-allyloxyphenyl)-1-isobutylimidazole (TH-68) have been found out. No correlation was observed between the ability of these imidazoles to cause precocious metamorphosis in B. mori and the degree of inhibition of $\mathrm{JH}$ synthesis in vitro in D. punctata. $\mathrm{KK}-42$ was most active in $B$. mori, but showed low activity in inhibition of $\mathrm{JH}$ synthesis in D. punctata. TH-27 was the best inhibitor of $\mathrm{JH}$ synthesis in D. punctata but 45 -fold less active than KK-42 in B. mori.

Precocious pupation can be induced by allatectomy at the time of the third ecdysis. There was a quite difference in critical times between allatectomy and KK-42 treatment for induction of precocious pupation in the silkworm. KK-42 also delayed significantly the pigmentation of compounds eyes and adult emergence when applied to the newly ecdysed pupae of the silkworm. These results suggested that KK-42 caused temporary inhibition of ecdysteroid secretion rather than $\mathrm{JH}$ secretion. In fact, KK-42 was found to inhibit ecdysteroid synthesis in vitro in the prothoracic glands of $B$. mori and its $I_{50}$ value was approximately $1 \mathrm{nM}$. When KK-42 was applied to the 4th instar larvae of the silkworm, ecdysteroid titers in the hemolymph were remarkably reduced and remained at a trace level for at least 6 days, but begin to increase thereafter.

The activity of 1,5-disubstituted imidazoles to cause precocious pupation was completely counteracted by the simultaneous application of tebufenozide (RH-5992), a non-steroidal ecdysteroid agonist as well as by the dietary administration of 20-hydroxyecdysone. This fact also indicates that these imidazoles temporarily depressed the ecdysteroid titer in the larval hemolymph to induce precocious pupation. Although the precise mode of action of imidazoles including KK-42 is still unknown, cytochrome P450 monooxygenases involved in the ecdysteroid biosynthesis pathways from phytosteroids in insects might be the most possible target. KK-110 has been found to inhibit P450-dependent microsomal ecdysone 20-monooxygenase of fat bodies in the fleshfly larvae.

\section{INSECTICIDAL ACTIVITY}

None of 1,5-disubstituted imidazoles induced preco- 
cious pupation in the large milkweed bug, Oncopeltus fasciatus, but several compounds showed delayed toxicity; the treated nymphs died during or immediately after the molt. Among the compounds tested, the 1isobutyl analogs such as 1-isobutyl-5-(3-phenoxyphenyl)imidazole (TH-32) and TH-58 showed high activity, whereas KK-42 did not cause any molting abnormalities even at high doses. When TH-32 and TH-58 were applied to the newly molted 5 th instars at $500 \mu \mathrm{g} /$ dish, all treated nymphs were unable to shed their larval exuviae and failed to ecdyse to adults. There was a lack of correlation between the ability of 1,5-disubstituted imidazoles to cause precocious metamorphosis in B. mori and delayed toxicity in $O$. fasciatus. $\mathrm{TH}-32$ and $\mathrm{TH}-58$ also showed considerably high insecticidal activity against the larvae of the brown rice planthopper, Nilaparvata lugens.

\section{REGULATION OF DIAPAUSE}

Diapause of insects is known to occur in various developmental stages such as egg, larva, pupa or adult, and is controlled by central endocrine system. The silkmoth, Antheraea yamamai, and the gypsy moth, Lymantria dispar japonica, enter diapause at a late stage of embryonic development, just after the formation of pharate first-instar larvae. It had not been found possible to break this diapause by artificial means other than by chilling the eggs for a few months. Suzuki et al. have recently found that $\mathrm{KK}-42$ and a number of imidazoles completely terminated the diapause of the silkmoth and gypsy moth. In this case neither $\mathrm{JH}$ nor ecdysteroid was involved in diapause termination. A new endocrine mechanism responsible for the regulation of the diapause of pharate first-instar larvae, the presence of a repressive factor and a maturation factor, is suggested.

The injection of KK-42 into fifth instar larvae of the silkworm (Daizo strain), which had been destined to produce diapause eggs, induced the moths to lay nondiapause eggs. The critical period for KK-42 injection in the induction of non-diapause eggs was 24 to $72 \mathrm{hr}$ after the fourth ecdysis. KK-42 may disturb some chemical messages for diapause induction that are stored during the larval stages, which are transduced from the environmental signals received during the embryonic stages.

\section{BLEACHING ACTIVITY}

1-Ethyl- and 1-propyl-5-substituted imidazoles have been found to cause distinct chlorosis of lettuce seedlings. Both substituents at the 1- and 5-position of the imidazole ring were indispensable for this activity. Of the series of compounds tested, 5-(4-chlorophenyl)-1-propylimidazole and 5-[4-(3-methylbenzyl)phenyl]-1-propylimidazole showed the highest activity. These compounds markedly reduced $\beta$-carotene content as well as chlorophyll in plants. Inhibition of $\beta$-carotene formation was accompanied by an accumulation of some amounts of phytoene, a precursor of $\beta$-carotene. Since only 1,5 disubstituted imidazoles showed bleaching activity, it is reasonable to postulate that these imidazoles may inhibit a P450 system involving chlorophyll formation or carotenoid biosynthesis. 